\title{
College Costs, Freshman Enrollment, and Student Quality: Evidence from an Urban State University
}

\author{
Su-Jane Chen
}

\begin{abstract}
This research examines the impact of rising college costs on first-time, full-time resident freshman enrollment and quality at a large, urban, public teaching university in the time period 2001-2013. Test results show that freshman enrollment reacts significantly negatively to full-time tuition and fees, with the price elasticity surpassing unity in 2012 and 2013. The steadily increasing education cost has priced out a majority of incoming freshmen who are in the bottom quarter of their high school graduating class, student quality raised from punishing presumably the most economically disadvantaged group. This study also investigates how the university's freshman enrollment responds to tuition and fees charged by its two peers located on the same campus, a state research institution and a community college. No competitive threat comes from the research institution, suggesting that the two universities are in different market enclaves. In contrast, a weak substitution effect is documented between the target institution and the community college. Thus, it is important for the teaching institution to monitor the community college's price as well as its own. In light of President Obama administration's intention to make community colleges virtually free of cost, this realization could not have come at a more critical point.
\end{abstract}

Index Terms-Freshman enrollment, price elasticity, student quality, tuition and fees.

\section{INTRODUCTION}

Colorado for years has been one of the lowest-funded states for higher education. According to [1], the state's funding cut of $15.4 \%$ in 2011 from 2010 is twice as much as the national average of $7.6 \%$ and tops all but four states. Based on the net tuition as a percent of public higher education total educational revenue published by the State Higher Education Executive Officers Association in [2], Colorado's public funding for higher education fares worse than all but three states. Tuition accounts for about $70 \%$ of the total educational revenue received in 2012 by the state's public higher education, far exceeding the national average of $47 \%$. The Colorado Commission on Higher Education shows in [3] that the state's per resident student higher education funding has shrunk from $68 \%$ in $2000-01$ to $32 \%$ in 2012-13. The burden of funding shortage has been shifted to students with higher tuition. To address the ever-diminishing funding, Colorado legislature in 2010 has empowered state colleges and universities to set their own tuition for the 5-year period of 2011-2015. State institutions have since responded with significant tuition hikes.

Manuscript received February 11, 2015; revised April 23, 2015. The research went through significant revision while the author was on sabbatical leave from her institution.

Su-Jane Chen is with the Department of Finance, Metropolitan State University of Denver, Denver, CO 80217 USA (e-mail: chens@msudenver.edu).
The higher education institution under study is a large, four-year, urban public teaching institution founded in 1965 with a noble mission of providing quality accessible education to Coloradans, particularly those residing in the seven-county Denver metropolitan area. Given its unique mission, the university holds an open admission policy for all applicants except first-time freshmen under 20 years of age. Since its establishment, it has educated more undergraduate Coloradans than any other institutions in the state. According to the university, $97.4 \%$ of its students in Fall 2014 are Colorado residents and $92.7 \%$ of the student body comes from the seven counties in the Denver metro area. The university has consistently charged the lowest tuition and fees among all Colorado four-year institutions despite its urban location and associated higher cost of living. This definitely contributed to the university's touted recognition by Kaplan/Newsweek in 2000 as one of the 33 Best Values in Higher Education.

The university's affordability, however, has undoubtedly taken a big hit from its unprecedented, consecutive double-digit tuition rate increase over the 2009-2012 period. Its $22.6 \%$ hike of full-time in-state tuition increase in 2011 topped all its in-state peers. Its $18.10 \%$ increase in tuition and fees also was the most among all Colorado public higher education institutions for the year. The increase was on top of the $12.28 \%$ and $12.48 \%$ increases administered by the university in the two years prior. This essentially represents a $50 \%$ jump in tuition and fees over a mere three-year period. The abruptly large changes in tuition and fees are particularly harmful to lower income students, a significant portion of the institution's student body. Based on the university's Fall 2013 census of undergraduates, $32.8 \%$ are minorities, $31 \%$ are first-generation students, and $31.8 \%$ are PELL grant eligible. Thus, the excessive rise in tuition and fees may result in a disproportionately large drop in enrollment, which could push the university into a financial downward spiral. Therefore, it is critical to examine the impact of rising education costs on freshman enrollment.

As noted by [4], [5], lower-income students are more price responsive than their better-to-do peers. If so, a steady, significant increase in the university's tuition and fees over the study period of 2001-2013 may price out students from the low-income group at a disproportionate rate, especially during economic downturns in the early and late 2000s. Given a positive relationship between family income and student academic achievement, rising education costs could actually lead to an improvement in student quality. Arguably, though, the university may try to compensate for the adverse impact of tuition and fees on enrollment and revenue by lowering its admission standards. If so, rising costs could mean deteriorating student quality. Thus, the impact of tuition and fees increase on student quality, if any at all, 
remains to be seen. It depends on which factor, family income or admission standards, wields a bigger influence. The study intends to shed some light on the impact of tuition and fees on student quality and fill the void in literature.

The teaching-oriented university shares the same campus located in downtown Denver with two other state institutions, a four-year research institution and a community college. This unique feature affords Colorado college applicants drawn to the convenient urban location three potential choices to start their undergraduate education. Other than their missions, program offerings, and tuition and fees, the three institutions should be rather homogeneous. This homogeneity provides an ideal, unique setting for the study to explore if and how the freshman enrollment at the university is affected by tuition and fees charged by its two sister institutions on the same campus.

The relationship between costs and enrollment for higher education is hard, if not impossible, to generalize. The relationship for a national study may differ from that for an individual institution and may change over time. This research intends to shed additional light on this regard by studying the impact of tuition and fees on freshman enrollment for a large, urban, public teaching university over a recent time period. While ample studies have been focused on the effect of college costs on student enrollment, the literature has rarely looked into the impact of these costs on student quality. This study shall fill the void by examining such a plausible relationship. The unique setting of the institution, being located on the same campus as a four-year state research institution and a community college, also provides a perfect avenue for the investigation of the cross-price elasticity of demand for education.

Consistent with previous empirical work, test results in this study clearly demonstrate a significant absolute price effect on freshman enrollment. Different from major findings in the past, though, the price elasticity is generally high and eventually surpasses unity. In line with [6], the research documents a "two bands of tuition sensitivity," with year 2007 as the turning point. Therefore, the two-tier price sensitivity phenomenon exists in public as well as private four-year institutions. Empirical evidence in this research further suggests a significantly positive relationship between tuition and fees and student quality. In comparison, limited prior research in this aspect shows either irresponsiveness of student quality to price due to sizable excessive demand or negative sensitivity as a result of quality students being deterred by high price. The sharp difference could be attributed to the fact that the few prior student quality studies, unlike the current one, were performed on highly selective universities or top-ranked private, liberal arts colleges. Thus, as argued by [7], price sensitivity of student quality can only be dealt with at each specific institution. This study finds some weak evidence in support of the substitution effect between the university and its community college peer located on the same campus. The finding sets this study apart from the general conclusion drawn previously - students respond more to absolute price than to relative price between competing institutions. No substation effect is evidenced between the university and its on-campus state research institution, suggesting that the two are not in the same market enclave.
The rest of the paper is organized as follows. Section II provides literature review. Section III covers data and methodology. Section IV presents empirical findings. Section $\mathrm{V}$ concludes this study.

\section{LITERATURE REVIEW}

Empirical work supports an inverse relationship between costs and enrollment in higher education. Reference [8] performed a meta-analysis on 25 studies published between 1967 and 1982 that examined relationship between college costs and enrollment. It concluded that a $\$ 100$ increase in tuition (in 1982 dollars) would result in a 0.6 to 0.8 percentage point drop in first-time freshman enrollment. Reference [9], using tuition and enrollment data for public higher education institutions in all 50 states over the 1980-1992 period, stated that total enrollment at four-year colleges would decline by 1.4 percentage points for every $\$ 1,000$ tuition hike (in 1991 dollars). Reference [10] updated [8]by reviewing approximately 20 demand studies published in the 1980s and 1990s. It claimed that a $\$ 100$ tuition increase would yield a decrease in enrollment in the range of 0.5 to 1.0 percentage point. In general, prior studies based on national data suggest that the demand for higher education is relatively price insensitive. References [11], [12] even went as far as saying that tuition increase (within a reasonable range) has no bearing on enrollment of highly selective institutions or liberal arts colleges due to their huge, excessive demand. In contrast, [13], studying exclusively U.S. private colleges and universities, concluded that even a small change in tuition would trigger a huge response in enrollment. Reference [14], probing the effect of tuition and fees on enrollment for all public four-year colleges and universities in a more recent era, 1991 to 2007, discovered that abnormally large tuition hikes could cause disproportionate drop in enrollment.

While [5] cautioned that general conclusions drawn at the national level may not be readily transferrable to a specific state environment, let alone a particular university, research investigating the impact of tuition changes on enrollments at the level of specific, single institutions has, more or less, reached the same conclusion. That is, enrollment demand is rather inelastic to changes in price, [5], [15]-[21]. Reference [22] cautioned, though, that the relative inelastic price sensitivity could be significantly augmented when factoring in competition. Its examination of tuition and enrollment of a private, church-affiliated, comprehensive university in the Midwest led to the conclusion that the significant competition the institution faced from the private sector within the region had pushed the institution's gross and net price elasticity of demand for education above unity.

Extensive research has studied the impact of tuition price increase on enrollment but rarely has the literature addressed the effect of rising education costs on student quality. Reference [18] sampled two programs at the University of Minnesota, a liberal arts doctoral program and a professional program, in 1971-1972 and concluded that student quality is mostly price insensitive despite a $50 \%$ increase in tuition. However, the result is most likely only applicable to institutions of comparable quality and thus demand. Reference [23] studied 174 private undergraduate institutions 
in 1981 and documented a positive relationship between tuition and student quality. It attributed the finding to tuition being perceived as an index for institutional quality. If so, more expensive colleges and universities attract better quality students. Reference [7] examined the price elasticity of student quality, using the top 50 U.S. News and World Report ranked private, non-profit liberal arts colleges in 2008. With percentage of incoming freshmen ranked in the top ten of their high school class and the average institutional SAT scores as the two student quality indicators, the study suggested that student quality is significantly negatively affected by changes in tuition and is more price elastic for lower ranked schools characterized by smaller amount of student quality.

When a college increases its tuition and fees, its enrollment should decline. However, the college may actually experience an enrollment surge if its cost increase is less than that of its competitors. Such a substitution effect is documented in [6], [24]-[27]. These studies exhibited a significantly positive effect of competitive tuition on enrollment. References [4], [7] further showed that relative price between competing institutions elicits more response from college enrollment than absolute price.

\section{DATA AND METHODOLOGY}

\section{A. Data}

Table I contains the description of data gathered for the study over 2001-2013 sample period. The first-time, full-time resident freshman enrollment (freshman enrollment hereafter) and student quality data for each fall at the university under study are extracted from the common data set prepared annually by its Office of Institutional Research. The two most extreme freshman ranking statistics compiled by the university, percentages of freshmen ranked, respectively, in the top tenth and bottom quarter of their graduating high school class (top-quality and bottom quality students, hereafter, correspondingly), serve as the student quality indicator. The tuition and fees data for the three higher education institutions located on the same campus are derived from various years of Tuition and Fees Report prepared by the Colorado Commission on Higher Education.

The university, except for 2012 with respect to its campus research peer, has raised its tuition and fees at a drastically faster rate since 2008 economic downturn than either of its two campus counterparts. Its total percentage change in the cost for the post-2008 era stands at a whopping rate of $77.23 \%$, outpacing its two peers' respective rates of $50.92 \%$ and $49.05 \%$ by more than a $50 \%$ margin. The university, as also revealed in the table, enjoyed a positive growth in freshman enrollment for most of the last decade despite increasing tuition and fees, supporting a right shift of the demand curve for education during the time period. Since 2010, though, the university has seen a steady decline in its freshman enrollment. This reversal either reflects a left shift of the demand curve in 2010 or mirrors the dire consequence of its dramatic increase in tuition and fees. The study should shed some light on the driving force behind this notable change in enrollment pattern. Moreover, the table depicts a general downward trend for the poor-quality students. In comparison, no clear time-series pattern is detected for the top-quality students.

TABLE I: DESCRIPTION OF SAMPLE DATA

\begin{tabular}{|c|c|c|c|c|c|c|c|}
\hline & & \multicolumn{3}{|c|}{ Tuition and Fees } & \multicolumn{2}{c|}{$\begin{array}{c}\text { Freshman Rank Percentage } \\
\text { Quality Indicator) }\end{array}$} \\
\hline Year & Enrollment & University $(\$)$ & $\begin{array}{c}\text { Annual Change } \\
(\%)\end{array}$ & Peer 1 (\$) & Peer 2 (\$) & Top 10th & Bottom 25th \\
\hline 2001 & 1,701 & 2,338 & & 2,934 & 1,671 & 5 & 16 \\
\hline 2002 & 1,708 & 2,463 & 5.35 & 3,242 & 1,753 & 4 & 17 \\
\hline 2003 & 1,816 & 2,565 & 4.14 & 3,706 & 1,731 & 3.7 & 16.8 \\
\hline 2004 & 1,958 & 2,598 & 1.29 & 3,978 & 1,749 & 3.8 & 18.7 \\
\hline 2005 & 1,925 & 2,745 & 5.66 & 4,714 & 1,898 & 3.8 & 14.4 \\
\hline 2006 & 1,840 & 2,837 & 3.35 & 4,863 & 1,945 & 1.6 & 18.7 \\
\hline 2007 & 2,071 & 3,033 & 6.91 & 5,723 & 2,248 & 0.24 & 15.15 \\
\hline 2008 & 2,059 & 3,241 & 6.86 & 6,279 & 2,942 & 4.6 & 15.6 \\
\hline 2009 & 2,110 & 3,639 & 12.28 & 6,542 & 3,196 & 7 & 14 \\
\hline 2010 & 1,984 & 4,093 & 12.48 & 7,099 & 3,525 & 5 & 15 \\
\hline 2011 & 1,810 & 4,834 & 18.10 & 7,702 & 3,828 & 6 & 11 \\
\hline 2012 & 1,693 & 5,341 & 10.49 & 8.940 & 4,112 & 6 & 12 \\
\hline 2013 & 1,684 & 5,744 & 7.55 & 9,476 & 4,385 & 6.8 & 12.6 \\
\hline
\end{tabular}

The enrollment denotes first-time, full-time resident freshman enrollment, fall semester. Peers 1 and 2 stand for the university's two campus sister institutions, a research institution and a community college, respectively.

\section{B. Methodology}

While tuition affects the demand for education at an institution, there are non-tuition and fees demand affecting factors, especially systematic variables such as demography and economy, which are beyond the control of any institution. To separate the tuition and fees effect from the non-tuition and fees effect and to investigate the impact of college costs on freshman enrollment, an ordinary least squares (OLS) regression equation employed by [28] is adopted and expressed next.

$$
N_{t}=a+b_{1} C_{t}+b_{2} D_{t}+e_{t}
$$

where $a$ is the intercept term and $N_{t}, C_{t}, D_{t}$, and $e_{t}$ are the freshman enrollment number, the tuition and fees cost in 
dollars, a dummy variable for time aimed to capture the non-tuition and fees factors, and the error term, respectively, for year $t$. Under the approach, the change in demand is assumed to be constant at all levels of tuition and fees. A significant, negative regression coefficient of $b_{1}$ would support the notion that tuition and fees greatly, adversely affect freshman enrollment. As evidenced in Table 1 and noted earlier, the demand curve for education over the last decade, a dominating portion of the sample period, went through right shifts. If so, the regression coefficient for the dummy time variable, $b_{2}$, is expected to be significantly positive. Once the regression is performed, the coefficient of price elasticity for year $t$ is calculated by multiplying regression coefficient $b_{1}$ by the quotient of the year's tuition and fees over freshman enrollment. This coefficient reflects the percentage change in freshman enrollment given one percentage change in tuition and fees. Following [14], [22], enrollment demand is also estimated by rerunning (1) after taking the log form of both freshman enrollment and tuition and fees.

To examine the relationship between student quality and tuition and fees, (1) in its log-log form will be performed with each of the two quality indicators, percentages of top-quality and poor-quality students in the freshman class, $\mathrm{Q}_{10}$ and $\mathrm{Q}_{75}$, as the dependent variable. Given the caliber of the university and low percentage of its freshmen ranked in the top 10th percentile of their respective graduating high school class, the rising education costs are not expected to have much impact on top-quality students. Conversely, if a positive relationship exists between family income and student academic performance, the university may see a significant improvement in student quality in terms of reduced percentage of bottom-performing freshmen since the aggressive pricing policy mostly likely will price out low-income students. If so, $b_{1}$, the price sensitivity of poor-quality students is expected to be statistically significantly negative.

To investigate if the university's freshman enrollment depends on the tuition and fees charged by its two campus peers, an OLS regression expressed below in (2) is performed.

$$
\begin{aligned}
& \ln \left(N_{t}\right)=\alpha+\beta_{1} \ln \left(C_{t}\right)+\beta_{2} D_{t}+ \\
& \beta_{3} \ln \left(C_{1, t}\right)+\beta_{4} \ln \left(C_{2, t}\right)+\varepsilon_{t}
\end{aligned}
$$

where $C_{1, t}$ and $C_{2, t}$ are tuition and fees charged by the university's two campus peers, a research institution and a community college in year $t$, respectively. A statistically significantly negative $\beta_{1}$ suggests that freshman enrollment responds to the absolute amount of tuition and fees while a statistically significantly positive $\beta_{3}$ and/or $\beta_{4}$ would support student responsiveness to relative education costs instead. As in (1), $\beta_{2}$ is expected to be significantly positive to signal a right shift of the demand curve for education.

\section{EMPIRICAL RESULTS}

This section covers test results derived from running regressions for the investigation of the price effect on freshman enrollment and on student quality and the substitution effect over the 2001-2013 periods.

\section{A. Price Effect}

\section{1) Price effect on enrollment}

Regression results generated from applying (1) to the 2001-2013 data for the investigation of the price effect on enrollment are presented in Table II. The linear regression of freshman enrollment on tuition and fees and the time dummy produces an adjusted $\mathrm{R}^{2}$ of 0.82 and a statistically significant F-ratio of 27.55 at the $1 \%$ significance level, suggesting that the model is a good fit for the data. The statistically significantly negative coefficient associated with the tuition and fees variable, $C_{t}$, confirms the well-established inverse relationship in the literature between enrollment and tuition. Based on the coefficient value of -0.3532 , for every $\$ 100$ increase in the university's tuition and fees, its freshman enrollment, on average, is expected to drop by 35 , ceteris paribus. In comparison, [14], using national data from 1991 to 2006, showed a more modest relationship between education cost and enrollment - a drop of 25 students per $\$ 100$ increase in tuition and fees. The documented difference in price elasticity may mean that the university faces a more elastic demand for education than the nation as a whole and/or that the price elasticity for higher education has increased in the recent past.

TABLE II: PRICE EFFECT ON FRESHMAN $N$ ROLLMENT

\begin{tabular}{cccccc}
\hline $\begin{array}{c}\text { Dependable } \\
\text { variable }\end{array}$ & \multicolumn{1}{c}{$C_{t}$} & $\ln \left(C_{t}\right)$ & $D_{t}$ & $R^{2}$ & F-Ratio \\
\hline$N_{t}$ & $\begin{array}{c}-0.3532 \\
(-7.40)^{* * * *}\end{array}$ & & $\begin{array}{l}100.7138 \\
(7.13)^{* * * *}\end{array}$ & 0.82 & $27.55^{* * *}$ \\
& & $\begin{array}{l}-0.9369 \\
(-6.12)^{* * *}\end{array}$ & $\begin{array}{l}0.0725 \\
(6.02)^{* * *}\end{array}$ & 0.75 & $18.79^{* * *}$ \\
\hline
\end{tabular}

The $t$-statistics are in parentheses. The asterisk $\left(^{* * *}\right)$ denotes statistical significance at the $1 \%$ significance level. $N$ is the freshman enrollment, $C$ is the education cost measured by the university's tuition and fees, and $D$ is the dummy variable for time aimed to capture the non-tuition and fees factors.

Empirical evidence derived from the log-log form of (1) shows that the overall price sensitivity over the period stands at a stunning -0.9369 , indicating that enrollment is on the verge of becoming price elastic. Note that this study assumes that the university's cost-setting policy is independent of its admission policy. If the university has in fact lowered its admission standards in order to compensate for rising tuition and fees and to meet enrollment targets, then the cost effect is likely to be underestimated. Moreover, not only the enrollment but also the student quality could be adversely affected by a large increase in tuition and fees. The latter plausibility is addressed next when empirical evidence pertaining to price sensitivity of student quality is presented. In contrast, the significantly positive coefficient of the time variable, $D_{t}$, in both regression forms suggests that the demand curve over the sample period has shifted to the right as a result of factors other than tuition and fees.

Based on the cost coefficient of -0.3532 in the linear regression and annual tuition and fees and freshman enrollment data, the annul coefficient of price elasticity is derived accordingly by multiplying the regression coefficient value by the quotient of tuition and fees over freshman 
enrollment. Table III lists the resulting coefficient of price elasticity. Prior to 2012, the coefficient as shown in the table is consistently below unity, meaning that one percentage increase in tuition and fees would cause less than one percentage decrease in freshman enrollment. Thus, the freshman enrollment is relatively price inelastic and tuition and fees revenue during 2001-2011 would actually go up despite an unfavorable impact of tuition and fees on freshman enrollment. Apparently, the joint effect of non-tuition and fees factors on enrollment during the period captured by the time dummy was more than sufficient to offset the adverse effect from the tuition and fees increase. The observation provides further support to the notion that the demand curve over the period experienced consistent right shifts as evidenced earlier by the significant, positive regression coefficient associated with the dummy variable for time.

TABLE III: COEFFICIENT OF PRICE ELASTICITY, 2001-2013
\begin{tabular}{|l|c|c|c|}
\hline Year & Enrollment* & Tuition and Fees (\$) & Coefficient** \\
\hline 2001 & 1,701 & 2,338 & 0.49 \\
\hline 2002 & 1,708 & 2,463 & 0.51 \\
\hline 2003 & 1,816 & 2,565 & 0.50 \\
\hline 2004 & 1,958 & 2,598 & 0.47 \\
\hline 2005 & 1,925 & 2,745 & 0.51 \\
\hline 2006 & 1,840 & 2,837 & 0.54 \\
\hline 2007 & 2,071 & 3,033 & 0.52 \\
\hline 2008 & 2,059 & 3,241 & 0.56 \\
\hline 2009 & 2,110 & 3,639 & 0.61 \\
\hline 2010 & 1,984 & 4,093 & 0.73 \\
\hline 2011 & 1,810 & 4,834 & 0.94 \\
\hline 2012 & 1,693 & 5,341 & 1.11 \\
\hline 2013 & 1,684 & 5,744 & 1.20 \\
\hline
\end{tabular}

* denotes first-time, full-time resident freshman enrollment, fall semester. $* *$ denotes omitted negative sign for the coefficient.

Table III, however, depicts an alarming trend. The price elasticity of demand (in absolute value terms) increased steadily since 2009 after the economy took a dive in a global final meltdown. As the trend persisted, the coefficient eventually rose above unity in 2012 and further more in 2013, driving the demand for education proxied by freshman enrollment into the price elastic range. Thus, an increase in tuition and fees in 2012 and 2013 would actually drive down freshmen enrollment disproportionately and trigger a decline in tuition revenue.

Fig. 1 contains the demand curves derived from (1) for selected years. The demand curve, as illustrated, consistently shifted to the right year by year during this 13-year period. Fig. 1 further shows the tuition and fees-freshman enrollment relationship for two sub-sample periods, pre 2007 and post 2006. After all, year 2007 serves as an important defining moment, the year when tuition and fees broke the $\$ 3,000$ mark and the university started to raise its tuition and fees by more than $6 \%$ annually. The positive tuition-enrollment relationship over the pre-2007 period confirms the earlier observation that the favorable impact on enrollment from non-tuition and fees factors more than offsets the adverse effect on enrollment from the tuition and fees increase. The opposite occurred in the post-2006 period; the tuition-enrollment relationship turned negative. In spite of a continuing right shift of the demand curve, the move was not favorable enough to make up for the loss of enrollment due to drastic tuition and fees hikes. The sharp contrast between the two sub-periods provides further evidence to the "two bands of tuition sensitivity" identified by [6] in private four-year colleges. Thus, as speculated in [6], the two-tier price sensitivity phenomenon exists in public four-year colleges as well. In this specific case, when tuition and fees surpassed the threshold of $\$ 3,000$ and thus reached a higher level, students became more price sensitive than before.

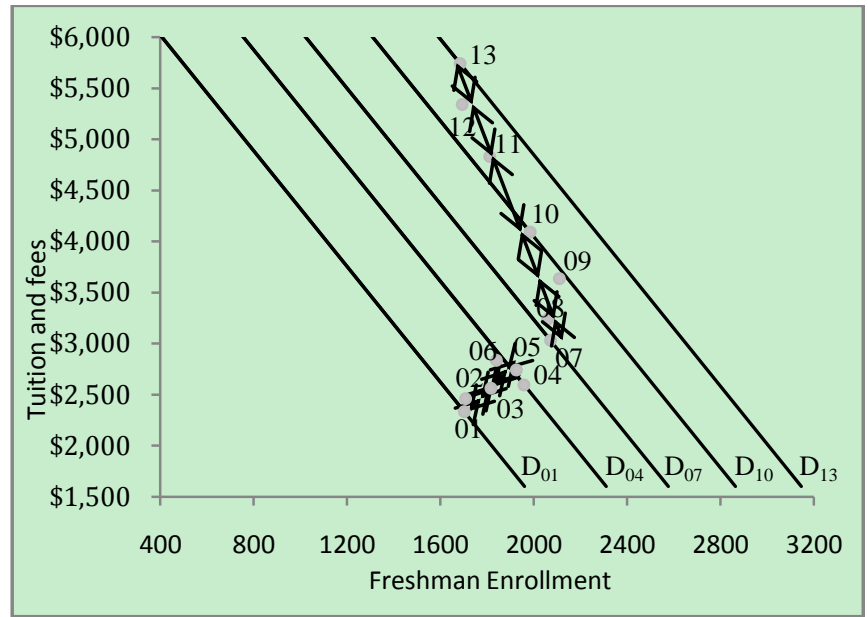

Fig. 1. Tuition and fees-freshmen enrollment relationship, 2001-2013.

\section{2) Price effect on student quality}

Empirical results presented in this section intend to provide some insights into the price elasticity of student quality, a topic rarely addressed in the literature, and thus to fill a void in the literature. Fig. 2 depicts the respective relationship between tuition and fees and the two student quality indicators, $\mathrm{Q}_{10}$ and $\mathrm{Q}_{75}$. It shows clearly that the percentage of poor-quality freshmen, those ranked at the bottom quarter of their high school class, has steadily declined as tuition and fees rose year by year. The trend is not as clear-cut for the top-quality group.

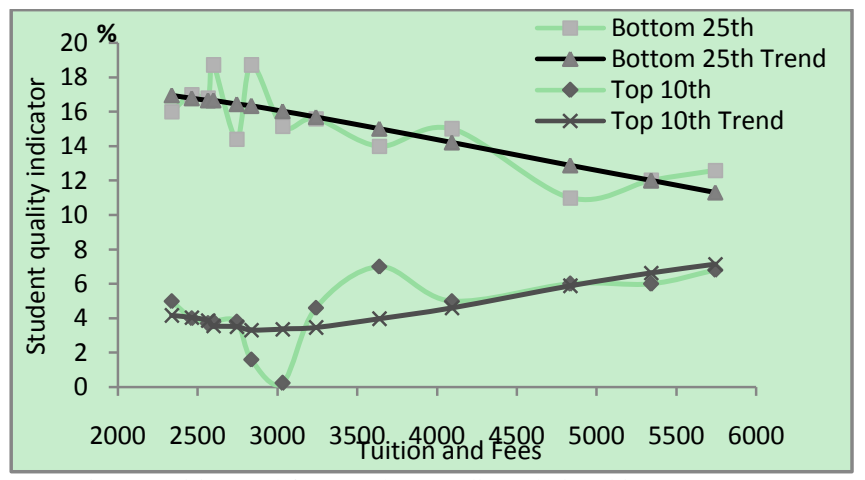

Fig. 2. Tuition and fees-student quality relationship, 2001-2013

Table IV covers test results generated from running the $\log -\log$ regression of (1) with the two student quality indicators as the respective dependent variable. Given the university's small percentage of top-quality freshmen, it does not come as a surprise that the resulting price coefficient in the first regression is not statistically significant. As a matter of fact, both the low adjusted $R^{2}$ and the small $F$-ratio indicate that the model is a poor fit for the data. A different 
picture emerges when the student quality is proxied by the percentage of freshmen whose high school academic performance landed them in the bottom quarter of their graduating class. The statistically significantly negative regression coefficient on tuition and fees suggests that the percentage of poor-quality freshmen in the university is a declining function of its education cost. Thus, as the tuition and fees cost charged by the university rises, the percentage of poor-quality freshmen falls, and vise versa.

As contemplated earlier in the paper, the impact of tuition and fees increase on student quality, if at all, depends on which of the two factors, family income or admission standards, exerts a bigger influence. If family income is the dominating force, then the student quality is expected to improve when rising college costs price out low-income and presumably poor-performing students. If admission policy plays a more pivotal role, then the student quality most likely will deteriorate as lowered academic standards lead to the acceptance and enrollment of low-quality students who otherwise would not have been admitted under a set of more rigid admission policy. Test results illustrated in Table IV point to the influential effect of family income on college affordability and, in turn, on student quality of the university. The finding represents a sharp contrast to limited evidence documented in the literature where student quality was found to be either insensitive or negatively related to price. The discrepancy can be attributed to the different characteristics possessed by the various institutions studied. Unlike this research, previous work conducted in the field examined students of either highly selective universities or top-ranked private, liberal arts colleges.

TABLE IV: PRICE EFFECT ON STUDENT QUALITY

\begin{tabular}{ccccc}
\hline $\begin{array}{c}\text { Dependable } \\
\text { variable }\end{array}$ & $\ln \left(C_{t}\right)$ & $D_{t}$ & $R^{2}$ & F-Ratio \\
\hline $\ln \left(Q_{10, t}\right)$ & $\begin{array}{c}5.8516 \\
(1.92)\end{array}$ & $\begin{array}{c}-0.3966 \\
(-1.6)\end{array}$ & 0.16 & 2.17 \\
$\ln \left(Q_{75, t}\right)$ & $\begin{array}{c}-0.7888 \\
(-2.29)^{* *}\end{array}$ & $\begin{array}{c}0.0284 \\
(1.04)\end{array}$ & 0.67 & $13.19^{* * *}$ \\
\hline
\end{tabular}

The $t$-statistics are in parentheses. The asterisks $\left({ }^{* *}\right)$ and $\left({ }^{* * *}\right)$ denote statistical significance at the $5 \%$ and $1 \%$ significance levels, respectively. $C$ is the education cost measured by the university's tuition and fees, $D$ is the dummy variable for time aimed to capture the non-tuition and fees factors, $Q_{10}$ and $Q_{75}$ are the two student quality indictors proxied by the percentage of freshmen in the top 10th and bottom 25 th rank of their high school class, respectively.

\section{B. Substitution Effect}

To examine whether the university's freshman enrollment is affected by tuition and fees charged by its two campus peers, a research institution and a community college, regression analysis expressed in (2) is performed on the 2001-2013 data. Table V contains the associated test results. The respective adjusted $R^{2 \text { s }}$ s of 0.77 and 0.79 , along with the statistically significant $F$-ratios, support good fitness of both models. Reproduced in the table is the log-log regression result derived earlier without either competing institution's price. As the table shows, the presence of competition boosts the absolute value of the university's own price elasticity by 0.16 percentage point.

The positive but insignificant regression coefficient loaded on the cost charged by the university's campus research peer suggests that the two state universities are most likely in different market enclaves and thus are not close competitors. To the extent of current pricing level, the teaching-oriented university does not appear to face a serious threat from its campus research peer. In contrast, the much more positive regression coefficient associated with the cost charged by the community college has a $p$ value of 0.1308 , suggesting that a substitution effect exists between the university and its campus community college peer. This competitive price effect is most likely understated given the limited sample size, a notion supported by the regression result obtained from rerunning (2) after dropping the nonfactor, $C_{1, t}$. The revised model specification raises the significance of the cross-price coefficient, making it marginally significant at the $10 \%$ significance level.

TABLE V: SUBSTITUTION EFFECT ON FRESHMAN ENROLLMENT

\begin{tabular}{ccccccc}
\hline $\begin{array}{c}\text { Dependent } \\
\text { Variable }\end{array}$ & $\ln \left(C_{t}\right)$ & $D_{t}$ & $\ln \left(C_{1, t}\right)$ & $\ln \left(C_{2, t}\right)$ & $R^{2}$ & F-Ratio \\
\hline $\ln \left(N_{t}\right)$ & -0.9369 & 0.073 & & & 0.75 & $18.79^{* * *}$ \\
& $(-6.12)^{* * * *}$ & $(6.02)^{* * *}$ & & & & \\
$\ln \left(N_{t}\right)$ & -1.0999 & 0.0609 & 0.0079 & 0.25 & 0.77 & $10.93^{* * *}$ \\
& $(-5.45)^{* * *}$ & $(1.16)$ & $(0.02)$ & $(1.68)$ & & \\
$\ln \left(N_{t}\right)$ & -1.1017 & 0.0619 & & 0.25 & 0.79 & $16.40^{* * *}$ \\
\hline
\end{tabular}

The $t$-statistics are in parentheses. The asterisk $\left({ }^{* * *}\right)$ denotes statistical significance at the $1 \%$ significance level. $N$ is the freshman enrollment, $C$ is the education cost measured by the university's tuition and fees, $D$ is the dummy variable for time aimed to capture the non-tuition and fees factors, $C_{l}$ and $C_{2}$ are tuition and fees charged by the university's two campus peers, a research institution and a community college, respectively.

a. The t-statistic of 1.80 is marginally significant at the $10 \%$ level with a $p$-value of 0.1059

In short, the university's freshman enrollment is affected to a greater extent by its own tuition and fees and to a lesser degree by the price charged by its campus community college peer, and most likely by that of all other community colleges located in the same Denver metropolitan area. Thus, if the university increases its tuition and fees at a faster rate than its community college counterparts in the state and becomes relatively more expensive, it may induce some people who otherwise would have enrolled themselves in the university to attend instead a state community college more readily accessible.

\section{CONCLUSIONS}

Consistent with the conventional notion, a negative impact of college costs on student enrollment is documented in this study, using tuition and fees and first-time, full-time resident freshman enrollment data at an urban, state four-year teaching institution for 2001-2013 period. However, deviating from the general conclusion drawn in the empirical literature that demand for higher education is rather price irresponsive, the freshmen at the university are found to be highly price sensitive. As a matter of fact, the price sensitivity at the institution has been steadily increasing at an alarming rate since the 2008 Great Recession, eventually turning elastic in 2012 with a coefficient of -1.11 , followed by -1.20 in 2013. Thus, an increase in tuition and fees by the institution since 2012 has caused a decline in not only freshman enrollment but also tuition revenue. As a result, the university can no longer rely on tuition and fees increase as a revenue enhancing mechanism. While the finding may be 
institution specific, empirical evidence derived from the usage of up-to-date data in this study may as well imply that college students have become more price conscientious over the recent past. This calls for all colleges and universities to monitor the movement of their enrollment and price even more closely than before.

This research also documents a "two bands of tuition sensitivity," with year 2007, the year when tuition and fees breaking the $\$ 3,000$ threshold, as the turning point. It validates the contention of [6] that the phenomenon exists in public as well as private four-year institutions. Empirical evidence further suggests a significantly positive relationship between tuition and fees and student quality in the sense that poor-quality students as a percentage of freshman class decline as tuition and fees increase, setting this study apart from the few prior research conducted in this aspect. Limited previous empirical work studied exclusively highly selective universities or top-ranked private, liberal arts colleges and focused solely on the relationship between price and top-quality students. Thus price sensitivity of student quality, as argued by [7], can only be dealt with at each specific institution. Unfortunately, though, the improved student quality at the institution most likely comes at the expense of the most economically disadvantaged group as the high education cost prices out the low-income group given the long established linkage between poverty and academic performance. For a university that prides itself as a provider of an affordable quality education and with a large portion of its students qualified for PELL grant, the finding should prompt the university to take a closer look at its pricing and financial aid policies.

This study finds no substitution effect between the university and its campus state research institution, suggesting that the two are not in the same market enclave. In contrast, it documents a weak cross-price effect between the university and its on-site community college, shedding additional light on the dynamic between public four-year university enrollment and public-two year college tuition and fees. The effect is most likely underestimated given the small sample size. Furthermore, it is highly probable that the competition goes beyond the on-campus community college. To be more specific, the university's enrollment may be sensitive to the price set by some other state community colleges as well when potential students deterred by the institution's high tuition and fees decide to enroll instead in a community college more readily accessible.

Thus, while the university's freshman enrollment is more heavily affected by its own tuition and fees and less so by its community college peer's, it is imperative for the university to incorporate the tuition and fees set by in-state community colleges into its own price setting decision. For the university whose student body is mainly made up of in-state residents and other institutions alike, the common practice of comparing their costs with a national peer average, e.g. the average of NCHEMS peers, is no longer sufficient. This realization is especially critical in today's economic environment in which funding for college education has plummeted and public institutions, in response, have been scrambling with tuition and fees hikes. Further heightening the issue is President Obama's plan to provide virtually cost-free education at community colleges. It is crucial for the university and other comparable four-year state institutions to collaborate closely with their in-state community colleges in hope that the students they miss out at the freshman year due to their higher college charges will flow back once these students complete their associate degree at a community college.

\section{REFERENCES}

[1] E. Kelderman. (2012). State support for colleges falls $7.6 \%$ in 2012 fiscal year. The Chronicle of Higher Education. [Online]. Available: http://chronicle.com/article/State-Support-For-Higher/130414/?sid=at \&utm_source=at\&utm_medium=en

[2] State Higher Education Executive Officers Association. (2013). State Higher Education Finance FY 2012. [Online]. Available: http://sheeo.org/sites/default/files/publications/SHEF-FY12.pdf

[3] Colorado Commission on Higher Education. (2012). Tuition and fees report: Fiscal Year 2012-13. [Online]. Available: http://highered.colorado.gov/Publications/Reports/Budget/FY2013/20 13_tuitionfeesreport.pdf

[4] J. Shin and S. Milton, "Rethinking tuition effects on enrollment in public four-year colleges and universities," Review of Higher Education, vol. 29, no. 2, pp. 213-237, 2006.

[5] J. Wetzel, D. O'Toole, and S. Peterson, "An analysis of studen enrollment demand," Economics of Education Review, vol. 17, no. 1, pp. 47-54, 1998 .

[6] G. A. Bryan and T. W. Whipple, "Tuition elasticity of the demand for higher education among current students: A pricing model," Journal of Higher Education, vol. 66, no. 5, pp. 560-574, 1995.

[7] A. Wright. (2008). An analysis of tuition and enrollment in higher education: measuring price elasticity. Doctoral dissertation, Department of Economics, University of Richmond, Richmond, VA. [Online]. Available: https://dspace.lasrworks.org/handle/10349/658

[8] L. L. Leslie and P. T. Brinkman, "Student price response in higher education," Journal of Higher Education, vol. 58, no. 2, pp. 181-204, 1987.

[9] T. J. Kane. (1995). Rising public college tuition and college entry: How well do public subsidies promote access to college? (NBER Working Paper No. 5164). [Online]. Available: http://www.nber.org/papers/w5164.pdf

[10] D. E. Heller, "Student Price Response in higher education: An update to Leslie and Brinkman," Journal of Higher Education, vol. 68, no. 6 , pp. 624-659, 1997

[11] C. T. Clotfelter, "Demand for undergraduate education," in Economic Challenges in Higher Education, C. T. Clotfelter, R. G. Ehrenberg, M. Getz, and J. J. Siegfried, Eds., Chicago, IL: University of Chicago Press, 1991, pp.19-139.

[12] J. F. O'Connell and G. M. Perkins, "The economics of private liberal arts colleges," Journal of Business, vol. 76, no. 3, pp. 499-514, 2003.

[13] D. Epple, R. Romano, and H. Sieg, "Admission, tuition, and financial aid policies in the market for higher education," Econometrica, vol. 74, no. 4, pp. 885-928, 2006.

[14] S. W. Hemelt and D. E. Marcotte, "The impact of tuition Increases on enrollment at public colleges and universities," Educational Evaluation and Policy Analysis, vol. 33, no. 4, pp. 435-457, 2011.

[15] A. K. Dickey, E. J. Asher, and R. B. Tweddace, "Projecting head count and credit hour enrollment by age group, gender and degree level," Research in Higher Education, vol. 30, no. 1, pp. 1-19, 1989.

[16] R. G. Erhenberg and D. R. Sherman, "Optimal financial aid policies for a selective university," Journal of Human Resources, vol. 19, no. 2, pp 202-230, 1984.

[17] S. A. Hoenack and D. J. Pierro, "An econometric model of a public university's income and enrollment," Journal of Economic Behavior and Organization, vol. 14, no. 3, pp.403-423, 1990.

[18] S. A. Hoenack and W. C. Weiler, "Cost-related tuition policies and university enrollments," Journal of Human Resources, vol. 10, no. 3, pp. 332-360, 1975.

[19] T. D. Hopkins, "Higher education enrollment demand," Economic Inquiry, vol. 12, no. 1, pp. 53-65, 1974.

[20] R. L. Moore, A. H. Studenmund, and T. Slobko, "The effect of the financial aid package on the choice of a selective college," Economics of Education Review, vol. 10, no. 4, pp. 311-321, 1991.

[21] J. J. Seneca and M. K. Taussig, "The effects of tuition and financial aid on the enrollment decision at a state university," Research in Higher Education, vol. 26, no. 4, pp. 337-362, 1987.

[22] R. F. Allen and J. Shen, "Some new evidence of the character of competition among higher education institutions," Economics of Education Review, vol. 18, no. 4, pp. 465-470, 1999. 
[23] R. C. Dolan, C. R. Jung, and R. M. Schmidt, "Evaluating educational inputs in undergraduate education," The Review of Economics and Statistics, vol. 67, no. 3, pp. 514-520, 1985.

[24] D. E. Heller, "The effects of tuition and state financial aid on public college enrollment," Review of Higher Education, vol. 23, no. 1, pp 65-89, 1999.

[25] M. J. Hilmer, "Post-secondary fees and the decision to attend a university or a community college," Journal of Public Economics, vol. 67, no. 3, pp. 329-348, 1998.

[26] S. A. Hoenack and W. C. Weiler, "The demand for higher education and institutional enrollment forecasting," Economic Inquiry, vol. 17, no. 1, pp. 89-113, 1979.

[27] C. E. Rouse, "What to do after high school: The two-year versus four-year college enrollment decision," in Choices and Consequences: Contemporary Policy Issues in Education, R. G. Ehrenberg, Ed., Ithaca NY: ILR Press, 1994, pp. 59-88.
[28] H. J. Funk, "Price elasticity of demand for education at a private university," Journal of Educational Research, vol. 66, no. 3, pp 130-134, 1972

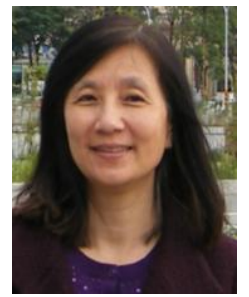

Su-Jane Chen received the Ph.D. degree in finance from University of Missouri-Columbia, USA, 1988. She is a professor and the former chair of Department of Finance, Metropolitan State University of Denver. Dr. Chen's research interests are in behavioral finance, capital budgeting, credit union industry, international finance, IPOs, REITs, and security pricing has led to numerous publications in refereed finance and economics journals, including Journal of Banking and Finance, Journal of Financial Research, and Real Estate Economics. She has served on a Colorado Credit Union's board of directors since 2002. 